\title{
Effect of Different Treatments of Calcium and Boron on Productivity and Fruit Quality of Navel Orange Fruits
}

\author{
A. R. F. Hikal, M. A. Ibrahim and R. A. Abdelaziz \\ Citrus Research Department, Horticulture Research Institute, Agricultural Research \\ Centre, Cairo, Egypt.
}

\begin{abstract}
$\mathbf{P}$ RODUCTIVITY, fruit setting, fruit drop, yield and fruit quality of Washington navel orange (Citrus sinensis L. Osbeck) trees in response to spraying both calcium chloride $\left(\mathrm{CaCl}_{2}\right)$ at $0.5,1.0,1.5$ and $2.0 \%$ and boric acid $\left(\mathrm{H}_{3} \mathrm{BO}_{3}\right)$ at $0.050,0.075,0.1 \%$ and $0.2 \%$ were evaluated during two successive seasons, 2014 and 2015 at El-Kanater El-Khayria research station, ElQalyubeiaGov., Egypt. The experimentwas designed as randomized complete block design with three replications. Results showed that most of boron treatments and the high concentrations ofcalcium applications were effective inimproving thefinal fruit set \%, yield $(\mathrm{kg})$, fruit quality as well as average fruit weight, average fruit volume, TSS (\%)and vitamin C ascompared to the control. They also, led to significant decrease in June-drop (\%) and juice acidity (\%). However, the best results with regard to fruit setting, yield and fruit quality were significantly obtained due to spraying trees with $0.2 \%$ boric acid followed by $2.0 \%$ Calcium chloride treatments. So, we may recommend to apply both of these treatments to maximize productivity and the net profits.
\end{abstract}

Keywords :Calcium, Boron, Washington navel orange, Fruit quality, Yield.

\section{Introduction}

Citrus is ranked the primary fruit crop in Egypt. It is the most economic fruit crop for local consumption and export. Washington navel orange is one of the most popular citrus varieties in Egypt, for its delicious taste and nutritional value, besides being rich in vitamin $\mathrm{C}$ and minerals. Its cultivated area reached 449266 feddans producing 4644450 tons of fruits annually according to The Annual Book of Agricultural Statistics, Cairo (2016). However, itsmoderate and/or low productivity of grownorchards is considered major and critical problem in Washington navel orange orchards. The lack of balanced nutrition is considered one among other factors which affect the growth, fruit setting and yield.

Applications of calciumand boron may partially help to over-come this problem. The application of calcium inhibits fruit abscission and delays its senescence development (Poovaiah and Leopold,1973), increase fruit pull force and firmness (Faust, 1975).

On the other hand, boron plays a major role in enhancing cell division, biosynthesis of carbohydrates and proteins, flowers pollination and fertilization and the movement of (Nijjar, 1985). It plays an important role in improving fruit setting through encouraging germination and growth of pollen grains (Chiu and Change 1985).

Regarding the similarity of B functions to other plant nutrients, Ca-B relationship is outstanding. Both elements play an important role in cell wall metabolism and are required for auxin transport process (Dela-Fuente et al., 1986). Additionally, $\mathrm{B}$ is involved in physiological and biochemical processes inside the plant cell, altering the concentration and translocation of nutrients (Tariq and Mott, 2007).

The purpose of this study wasto assistthe effectiveness of spraying calcium, and boron onthe productivity andfruit quality of Washington navel orange fruits.

\section{Materials and Methods}

This study was carried out during two successive seasons (2014 \& 2015) on 20 year- old Washingtonnavel orange trees (Citrus sinensis L. Osbeck) grown in the Experimental Farm at 
El-Kanater El-Khayria Res. Sta., El-Qalyubeia Gov., Egypt. The trees were planted at $5 \times 5 \mathrm{~m}$ and irrigated with surface irrigation system. Fifty four trees, as uniform as possible, were selected and sprayed with nine foliar applications. The treatments were as follows:

Control (Spraying with tapwater)

- $\quad 0.5 \%$ Calcium chloride (CaCL2)

- $\quad 1.0 \%$ Calcium chloride $\left(\mathrm{CaCL}_{2}\right)$

- $\quad 1.5 \%$ Calcium chloride $\left(\mathrm{CaCL}_{2}\right)$

- $2.0 \%$ Calcium chloride $\left(\mathrm{CaCL}_{2}\right)$

- $\quad 0.050 \%$ Boric acid $\left(\mathrm{H}_{3} \mathrm{BO}_{3}\right)$

- $\quad 0.075 \%$ Boric $\operatorname{acid}\left(\mathrm{H}_{3} \mathrm{BO}_{3}\right)$

- $\%$ Boric acid $\left(\mathrm{H}_{3} \mathrm{BO}_{3}\right)$

- $\quad 0.2 \%$ Boric acid $\left(\mathrm{H}_{3} \mathrm{BO}_{3}\right)$

A randomize complete block design with three replicates; two trees per each wereused. Treeswere fully sprayed with the specified solutions using a hand pressure sprayer three times a year i.e. at three weeks before flowering ( $2^{\text {nd }}$ week of Feb.), just after fruit setting ( $\left(1^{\text {st }}\right.$ week of April) and at one month later ( $1^{\text {st }}$ of May).

\section{Measurements and Determinations:}

Vegetative growth

- Shoot length $(\mathrm{cm})$.

- Shoot diameter $(\mathrm{cm})$

- Leaf area $\left(\mathrm{cm}^{2}\right)$ was measured (using mature leaf at the second week of September)using laserleaf area meter (model CI-203CA from CID. Inc. company).

\section{Fruit set and drop (\%)}

The final fruit set (\%),June drop (\%)and pre-harvest fruitdrop (\%) were estimated at 15 November during bothseasons as follows:

Final fruit set $(\%)=\frac{\text { Total number of fruits }}{\text { Total number of flowers }} \times 100$

June drop $(\%)=\frac{\text { Number of dropped fruits }}{\text { Total number of fruits }} \quad$ x 100

Pre-harvest fruit drop $(\%)=$

Number of dropped fruits under trees $\quad$ x 100 Total number of fruits on tree

\section{Yield components}

Fruit yield wasrecorded at harvest time (December) in both seasons expressed as number of fruits/tree and weight of fruits ( $\mathrm{kg} /$ tree) .

\section{Fruit quality}

Six fruitsamplesfor each treatment at harvest time (one/ each tree) in both seasons were taken in order to determine fruit quality; physical properties i.e. fruit weight $(\mathrm{g})$ and fruit size $\left(\mathrm{cm}^{3}\right)$ and chemical properties i.e. total soluble solids (TSS) using Carl Zeiss hand referactometer, total acidity as ( $\mathrm{g}$ ) of unhydrous citric acid, TSS/acid ratio and Vitamin $\mathrm{C}$ as $\mathrm{mg}$ ascorbic acid were determined and estimated per $\mathrm{mg} / 100 \mathrm{ml}$ juice, according to A.O.A.C. (1965).

Leaf mineral contents were determined as follows:

On March of both seasons, twenty spring shoots from all over the outer circumference of each treated tree were labeled for leaf samples. From each replicate, a sample of about 60 leaves was taken in the first week of October (each year) for the chemical analysis.

The collected leaf samples were washed with tap water, rinsed three times with distilled water and then oven dried at $70{ }^{\circ} \mathrm{C}$ to a constant weight. Leaf dried materials were ground in a stainless steel rotary knife with a mill 20 mesh.

The dried ground samplesweredigested with sulphuric acid and hydrogen peroxide. Suitable aliquots were taken for the determination of $\mathrm{N}$, $\mathrm{P}, \mathrm{K}, \mathrm{Ca}, \mathrm{Fe}, \mathrm{Zn}$ and $\mathrm{Mn}$ according to Chapman (1960) and Chapman and Pratt (1978).

\section{Macronutrients}

- Total nitrogen percentage in dry leaf samples was determined using the microkjeldahal method as described by A.O.A.C. (1965).

- Phosphorus was determined using ammonium venedate method as described by Chapman and Pratt (1978).

- Potassium was measured against a standard using Carlzesis Jena Flame Photometer.

- Calcium and magnesium were determined according to the wet aching method technique as reported by Jackson (1967), by using atomic absorption Spectorphotometer.

\section{Micronutrients}

- Zinc was determined according to Chapman (1960) directly in the original solution using atomic absorption spectorphotometer.

- $\quad \mathrm{Fe}$ and Mn were determined according to Evenhuis and De Waard (1980).

Statistical analysis

Experimental design was a complete randomized block design according to Snedecor and Cochran (1980). The averages were compared using New L.S.D. at 5\%. 


\section{Results}

Vegetative growth

Shoot length $(\mathrm{cm})$

Data presented in Table1 obviously reveal that, most of calcium and boron treatments significantly increased shoot length when compared to thecontrol in both seasons. Boric acid (0.2\%) treatment showed the highest effect (13.04 and $12.88 \mathrm{~cm}$ ) in both seasons, respectively. However control treatment had the lowest values $(9.65$ and $9.01 \mathrm{~cm})$ in both seasons, respectively.

\section{Shoot diameter (cm)}

Data presented in Table 1 obviously indicate that Washington navel orange shoot diameterwas significantlyaffected by $\mathrm{Ca}$ and $\mathrm{B}$ treatments when compared to control in both seasons. The best treatment in this regard was obtained by spraying B at $0.2 \%$ in both seasons 9.87 and 9.06 $\mathrm{cm}$, followed by spraying with $\mathrm{Ca}$ at $2 \%$ resulted at $(9.25$ and $8.71 \mathrm{~cm})$, respectively.

\section{Leaf area $\left(\mathrm{cm}^{2}\right)$}

Data obtained in Table 1 show that all treatments resulted in a slight increase with lack of significance for the majority of treatments as compared to control during the two study seasons. Nevertheless, application of B at $(0.20 \%)$ wasmore effective (126.58 and 123.79), than Ca at $(2.0 \%)$ resulting in 121.99 and $118.91 \mathrm{~cm}^{2}$ in the two seasons, respectively.

\section{Fruit set and drop}

\section{Final fruit set percentage}

Concerning the final fruit set percentage recorded in both seasons (Table 2) the dataobviously showedthat fruit set percentage was improved in treated trees compared with the control. The best functional treatments in this regard were foliar sprays of $\mathrm{B}(0.2 \%$ Boric acid $)$ and $\mathrm{Ca}\left(2.0 \% \mathrm{CaCL}_{2}\right)$ in both seasons where the results were $(4.48 \& 4.18 \%$ and $3.22 \& 3.20 \%$ ) in both seasons, respectively.

\section{Fruit June drop percentage}

According to data presented in Table 2 fruit June drop was decreased by the higher compared to control in both seasons. The best result was obtained by foliar sprays of $0.2 \%$ Boric acid treatment $(89.62 \%$ and $88.73 \%)$ followed by $2.0 \% \mathrm{CaCL}_{2}$ one $(90.01 \%$ and $89.66 \%)$ in both seasons, respectively.

\section{Pre-harvest fruit drop percentage}

Data presented in Table 2 disclosedthat the pre-harvest fruit drop percentage was positively affected bymost of treatments compared with the control in both seasons. Data revealed also that, the lowest value wasobtained by foliar sprays of boric acid at $0.2 \%$.

\section{Yield components}

\section{Fruits number/tree}

It is clear from the data presented in Table 3 that foliar sprays of $\mathrm{B}$ at $0.2 \%$ Boric acid followedby $\mathrm{Ca}\left(2 \% \mathrm{CaCl}_{2}\right)$ resulted in the highest number of fruit per tree. Also, average number of fruits/ tree was enhanced by most of treatments compared tocontrol trees. The best results, in this regard, were obtained by foliar B at $0.2 \%$ (302.58 and 289.46) in both seasons, respectively.

\section{Yield/tree $(\mathrm{kg})$}

Data presented in Table 3 declared that yield $(\mathrm{kg}) /$ tree was significantly increased in all foliar sprays of either of B or Ca treatments with lack of significance in general as compared tothe control. The most effectivetreatment was foliar sprays

TABLE 1. Effect of different treatments of calcium and boron on shoot length $(\mathrm{cm})$, shoot diameter (cm), leaves number/ shoot and leaf area $\left(\mathrm{cm}^{2}\right)$ of Washington navel orange trees during 2014 and 2015 seasons.

\begin{tabular}{lcccccc}
\hline \multirow{2}{*}{ Treatments } & \multicolumn{2}{c}{ Shoot length $(\mathbf{c m})$} & \multicolumn{2}{c}{ Shoot diameter $(\mathbf{c m})$} & \multicolumn{2}{c}{ Leaf area/shoot $\left(\mathbf{c m}^{\mathbf{2}}\right)$} \\
\cline { 2 - 7 } & $\mathbf{2 0 1 4}$ & $\mathbf{2 0 1 5}$ & $\mathbf{2 0 1 4}$ & $\mathbf{2 0 1 5}$ & $\mathbf{2 0 1 4}$ & $\mathbf{2 0 1 5}$ \\
\hline Control & 9.65 & 9.01 & 7.36 & 6.98 & 112.68 & 108.06 \\
$0.5 \% \mathrm{CaCL}_{2}$ & 10.79 & 10.14 & 8.34 & 7.98 & 113.50 & 108.78 \\
$1.0 \% \mathrm{CaCL}_{2}$ & 11.08 & 11.54 & 8.43 & 8.08 & 113.90 & 112.97 \\
$1.5 \% \mathrm{CaCL}_{2}$ & 12.16 & 12.17 & 9.47 & 8.64 & 120.10 & 118.12 \\
$2.0 \% \mathrm{CaCL}_{2}$ & 12.69 & 12.58 & 9.25 & 8.71 & 121.99 & 118.91 \\
$0.050 \%$ Boric acid & 11.43 & 11.54 & 9.55 & 8.54 & 116.16 & 115.09 \\
$0.075 \%$ Boric acid & 12.05 & 12.14 & 9.61 & 8.69 & 120.76 & 120.34 \\
$0.1 \%$ Boric acid & 12.77 & 12.64 & 9.73 & 8.83 & 123.05 & 120.78 \\
$0.2 \%$ Boric acid & 13.04 & 12.88 & 9.87 & 9.06 & 126.58 & 123.79 \\
New LSD 5\% & 1.52 & 1.21 & 1.13 & 1.09 & 8.21 & 9.07 \\
\hline
\end{tabular}


TABLE 2. Effect of different treatments of calcium and boron on final fruit set (\%), June and pre-harvest fruit drop (\%) of Washington navel orange trees during 2014 and2015 seasons.

\begin{tabular}{lcccccc}
\hline \multirow{2}{*}{\multicolumn{1}{c}{ Treatments }} & \multicolumn{2}{c}{ Final fruit set (\%) } & \multicolumn{2}{c}{$\begin{array}{c}\text { June drop } \\
(\%)\end{array}$} & \multicolumn{2}{c}{ Pre-harvest fruit drop (\%) } \\
\cline { 2 - 7 } & $\mathbf{2 0 1 4}$ & $\mathbf{2 0 1 5}$ & $\mathbf{2 0 1 4}$ & $\mathbf{2 0 1 5}$ & $\mathbf{2 0 1 4}$ & $\mathbf{2 0 1 5}$ \\
\hline Control & 2.12 & 2.08 & 93.18 & 92.65 & 3.67 & 3.38 \\
$0.5 \% \mathrm{CaCL}_{2}$ & 2.99 & 2.86 & 92.01 & 91.13 & 3.15 & 2.94 \\
$1.0 \% \mathrm{CaCL}_{2}$ & 3.11 & 3.06 & 91.74 & 90.65 & 3.03 & 2.89 \\
$1.5 \% \mathrm{CaCL}_{2}$ & 3.16 & 3.13 & 90.14 & 89.95 & 2.91 & 2.83 \\
$2.0 \% \mathrm{CaCL}_{2}$ & 3.22 & 3.20 & 90.01 & 89.66 & 2.89 & 2.76 \\
$0.050 \%$ Boric acid & 3.02 & 2.78 & 91.64 & 90.56 & 3.03 & 2.97 \\
$0.075 \%$ Boric acid & 3.32 & 3.11 & 91.03 & 89.94 & 2.93 & 2.83 \\
$0.1 \%$ Boric acid & 4.23 & 3.87 & 90 & 89.03 & 2.85 & 2.8 \\
$0.2 \%$ Boric acid & 4.48 & 4.18 & 89.62 & 88.73 & 2.76 & 2.74 \\
New LSD 5\% & 0.95 & 0.87 & 1.76 & 1.64 & 0.61 & 0.54 \\
\hline
\end{tabular}

TABLE 3. Effect of different treatments of calcium and boron onfruits number/ tree, yield (kg)/ tree, fruit weight (g) and fruit volume $\left(\mathrm{cm}^{3}\right)$ of Washington navel orange trees during 2014 and 2015 seasons.

\begin{tabular}{|c|c|c|c|c|c|c|c|c|}
\hline \multirow[t]{2}{*}{ Treatments } & \multicolumn{2}{|c|}{$\begin{array}{c}\text { Fruits number/ } \\
\text { tree }\end{array}$} & \multicolumn{2}{|c|}{$\begin{array}{c}\text { Yield }(\mathrm{kg}) / \\
\text { tree }\end{array}$} & \multicolumn{2}{|c|}{ Fruit weight (g) } & \multicolumn{2}{|c|}{ Fruit volume $\left(\mathrm{cm}^{3}\right)$} \\
\hline & 2014 & 2015 & 2014 & 2015 & 2014 & 2015 & 2014 & 2015 \\
\hline Control & 275.10 & 269.40 & 64.35 & 61.85 & 233.90 & 229.60 & 235.2 & 235.4 \\
\hline $0.5 \% \mathrm{CaCL}_{2}$ & 278.97 & 274.90 & 66.02 & 64.22 & 236.67 & 233.63 & 242.9 & 240.1 \\
\hline $1.0 \% \mathrm{CaCL}_{2}$ & 281.23 & 278.35 & 69.07 & 66.80 & 245.59 & 240.00 & 252.4 & 246.8 \\
\hline $1.5 \% \mathrm{CaCL}_{2}$ & 289.32 & 283.93 & 72.67 & 69.67 & 251.17 & 245.39 & 258.9 & 252.4 \\
\hline $2.0 \% \mathrm{CaCL} 2$ & 292.41 & 284.56 & 75.62 & 72.14 & 258.62 & 253.53 & 265.8 & 260.4 \\
\hline $0.050 \%$ Boric acid & 277.42 & 270.54 & 65.87 & 63.97 & 237.45 & 236.47 & 244.3 & 243.7 \\
\hline $0.075 \%$ Boric acid & 284.28 & 277.41 & 70.06 & 69.49 & 246.43 & 250.49 & 262.1 & 258.1 \\
\hline $0.1 \%$ Boric acid & 289.61 & 285.66 & 74.36 & 72.23 & 256.76 & 252.84 & 264.6 & 260.2 \\
\hline $0.2 \%$ Boric acid & 302.58 & 289.46 & 79.80 & 75.04 & 263.72 & 259.24 & 271.4 & 267.0 \\
\hline New LSD 5\% & 8.51 & 9.38 & 1.80 & 1.60 & 4.70 & 4.50 & 14.8 & 14.6 \\
\hline
\end{tabular}

of B (0.2\% Boric acid) 79.80 and $75.04 \mathrm{~kg}$, respectively. In the second season, average yields - as weight per tree- significantly increased by all foliar spray treatments compared tocontrol. The lowest values were attainedwith thecontrol trees (64.35 and 61.85) in the two seasons, respectively.

\section{Fruit quality}

\section{Physical properties}

The obtained data in Table 3 indicated that, foliar spraying with $\mathrm{B}$ or $\mathrm{Ca}$ enhanced average fruit weight and volume as compared with control treatment in both seasons. The data also showed that, Boric acid at the treatment at $0.2 \%$ followed by $\mathrm{CaCL}_{2}$ at $2.0 \%$, achieved significantly the highest values of average fruit weight and volume compared to control treatment in both seasons.

\section{Chemical properties}

Data in Table 4 demonstrated that all Catreatments had a minor positive effect concerning $\mathrm{TSS} \%$ and vitamin $\mathrm{C}$ while, it had noclear trend regardingTSS/acid ratio.
On the other hand,Boric acid at $0.2 \%$ was more effective in increasing TSS \%, and vitamin $\mathrm{C}$ content than all other treatments.Control treatment had the lowest TSS \% values for both seasons, while Boricacid at $0.2 \%$ achieved the highest figures in this concern.

\section{Leaf minerals composition \\ Macronutrients}

Concerning leaf $\mathrm{N} \%, \mathrm{P} \%, \mathrm{~K} \%$ and $\mathrm{Ca} \%$ and $\mathrm{M}$, the obtained data in Table 5 show thatfoliar spray with $\mathrm{Ca}$ had observable influence concerning leafmineral content especially lower concentrations. Whereas, Boric acid at $0.2 \%$ significantlyhave resulted in the highest values compared to control treatment in two seasons.

\section{Micronutrients}

Data illustrated in Table 6 showed that, B gave highly significant increase in leaf $\mathrm{Fe}, \mathrm{Zn}$ and $\mathrm{Mn}$ contents in both seasons. The lowest value was found with the control trees in the two seasons. 
Feasibility study

To evaluate the economic return for the examined treatments, a feasibility study was made up to settle onthe superlative treatment which had the best profit. Figures illustrated in Table 7 showed that, $0.2 \%$ boric acid treatments achieved the uppermost profits and the highest annualreturn of $16 \%$ on investment perfeddan. It worth to mention that, despite that the calcium price was less than boron but, its effective concentrations were nearly ten times of the boron ones which reflected in increasing the coast and consequently reduced the net profit for it.

TABLE 4. Effect of different treatments of calcium and boron on TSS, total acidity, TSS/acid ratio and vitamin C (mg/100ml juice) of Washington navel orange fruits during 2014 and 2015 seasons.

\begin{tabular}{lcccccccc}
\hline \multirow{2}{*}{ Treatments } & \multicolumn{2}{c}{$\begin{array}{c}\text { T.S.S } \\
(\%)\end{array}$} & \multicolumn{2}{c}{$\begin{array}{c}\text { Total acidity } \\
(\%)\end{array}$} & \multicolumn{2}{c}{$\begin{array}{c}\text { TSS/acid } \\
\text { ratio }\end{array}$} & \multicolumn{2}{c}{$\begin{array}{c}\text { Vitamin C } \\
\text { (mg /100ml juice) }\end{array}$} \\
\cline { 2 - 9 } & $\mathbf{2 0 1 4}$ & $\mathbf{2 0 1 5}$ & $\mathbf{2 0 1 4}$ & $\mathbf{2 0 1 5}$ & $\mathbf{2 0 1 4}$ & $\mathbf{2 0 1 5}$ & $\mathbf{2 0 1 4}$ & $\mathbf{2 0 1 5}$ \\
\hline Control & 12.1 & 12 & 1.32 & 1.22 & 9.15 & 9.81 & 46.6 & 45.7 \\
$0.5 \% \mathrm{CaCL}_{2}$ & 12.4 & 12.3 & 1.33 & 1.24 & 9.29 & 9.90 & 47.6 & 46.7 \\
$1.0 \% \mathrm{CaCL}_{2}$ & 12.5 & 12.5 & 1.32 & 1.23 & 9.44 & 10.14 & 48.3 & 47.6 \\
$1.5 \% \mathrm{CaCL}_{2}$ & 12.7 & 12.7 & 1.32 & 1.23 & 9.63 & 10.33 & 49.5 & 48.7 \\
$2.0 \% \mathrm{CaCL}_{2}$ & 12.8 & 12.7 & 1.32 & 1.23 & 9.67 & 10.32 & 49.9 & 49.7 \\
$0.050 \%$ Boric acid & 12.5 & 12.6 & 1.33 & 1.25 & 9.40 & 10.06 & 48.9 & 48 \\
$0.075 \%$ Boric acid & 12.7 & 12.8 & 1.32 & 1.29 & 9.62 & 9.95 & 50.2 & 49.6 \\
$0.1 \%$ Boric acid & 12.9 & 12.8 & 1.31 & 1.23 & 9.86 & 10.44 & 51.4 & 52 \\
$0.2 \%$ Boric acid & 13.0 & 13.0 & 1.30 & 1.22 & 9.97 & 10.64 & 54.8 & 53.9 \\
New LSD 5\% & 0.62 & 0.64 & 0.14 & 0.08 & 0.43 & 0.31 & 3.1 & 3.6 \\
\hline
\end{tabular}

TABLE 5. Effect of different treatments of calcium and boron on $\mathrm{N} \%, \mathrm{P} \%$, $\mathrm{K} \%$ and $\mathrm{Ca} \%$ of Washington navel orange leaf mineral contents during 2014 and 2015 seasons.

\begin{tabular}{lcccccccccc}
\hline \multirow{2}{*}{ Treatments } & \multicolumn{2}{c}{ Leaf N (\%) } & \multicolumn{2}{c}{ Leaf P (\%) } & \multicolumn{2}{c}{ Leaf K (\%) } & \multicolumn{2}{c}{ Leaf Ca (\%) } & \multicolumn{2}{c}{ Leaf Mg (\%) } \\
\cline { 2 - 11 } & $\mathbf{2 0 1 4}$ & $\mathbf{2 0 1 5}$ & $\mathbf{2 0 1 4}$ & $\mathbf{2 0 1 5}$ & $\mathbf{2 0 1 4}$ & $\mathbf{2 0 1 5}$ & $\mathbf{2 0 1 4}$ & $\mathbf{2 0 1 5}$ & $\mathbf{2 0 1 4}$ & $\mathbf{2 0 1 5}$ \\
\hline Control & 1.83 & 1.80 & 0.15 & 0.14 & 1.19 & 1.17 & 1.88 & 1.85 & 0.62 & 0.6 \\
$0.5 \% \mathrm{CaCL}_{2}$ & 1.97 & 1.96 & 0.19 & 0.18 & 1.29 & 1.26 & 1.98 & 2.01 & 0.65 & 0.62 \\
$1.0 \% \mathrm{CaCL}_{2}$ & 2.01 & 1.99 & 0.19 & 0.19 & 1.35 & 1.33 & 2.07 & 2.06 & 0.67 & 0.66 \\
$1.5 \% \mathrm{CaCL}_{2}$ & 2.00 & 2.07 & 0.20 & 0.20 & 1.39 & 1.37 & 2.10 & 2.09 & 0.68 & 0.67 \\
$2.0 \% \mathrm{CaCL}_{2}$ & 2.03 & 2.02 & 0.20 & 0.21 & 1.47 & 1.43 & 2.11 & 2.13 & 0.70 & 0.69 \\
$0.050 \%$ Boric acid & 2.02 & 1.97 & 0.18 & 0.19 & 1.30 & 1.27 & 1.99 & 2.01 & 0.64 & 0.63 \\
$0.075 \%$ Boric acid & 2.10 & 2.04 & 0.19 & 0.20 & 1.39 & 1.36 & 2.06 & 2.08 & 0.67 & 0.65 \\
$0.1 \%$ Boric acid & 2.14 & 2.10 & 0.21 & 0.21 & 1.45 & 1.41 & 2.09 & 2.10 & 0.69 & 0.68 \\
$0.2 \%$ Boric acid & 2.16 & 2.12 & 0.22 & 0.21 & 1.47 & 1.44 & 2.12 & 2.13 & 0.71 & 0.70 \\
New LSD 5\% & 0.17 & 0.19 & 0.05 & 0.05 & 0.17 & 0.14 & 0.19 & 0.17 & 0.06 & 0.05 \\
\hline
\end{tabular}

TABLE 6. Effect of different treatments of calcium and boron onleaf $\mathrm{Mg} \%$ and leaf (Fe, $\mathrm{Zn}$ and $\mathrm{Mn}$ ) of Washington navel orange leaf mineral contents during 2014 and 2015 seasons.

\begin{tabular}{lcccccc}
\hline \multirow{2}{*}{ Treatments } & \multicolumn{2}{c}{ Leaf Fe (ppm) } & \multicolumn{2}{c}{ Leaf Zn (ppm) } & \multicolumn{2}{c}{ Leaf Mn (ppm) } \\
\cline { 2 - 7 } & $\mathbf{2 0 1 4}$ & $\mathbf{2 0 1 5}$ & $\mathbf{2 0 1 4}$ & $\mathbf{2 0 1 5}$ & $\mathbf{2 0 1 4}$ & $\mathbf{2 0 1 5}$ \\
\hline Control & 83 & 80.32 & 67.51 & 66.14 & 57.38 & 54.83 \\
$0.5 \% \mathrm{CaCL}_{2}$ & 83.72 & 84.55 & 69.00 & 69.35 & 59.80 & 59.85 \\
$1.0 \% \mathrm{CaCL}_{2}$ & 86.48 & 84.64 & 75.81 & 70.84 & 64.44 & 60.72 \\
$1.5 \% \mathrm{CaCL}_{2}$ & 90.29 & 86.40 & 75.70 & 74.68 & 64.89 & 64.54 \\
$2.0 \% \mathrm{CaCL}_{2}$ & 90.20 & 88.32 & 76.50 & 74.63 & 65.12 & 65.85 \\
$0.050 \%$ Boric acid & 84.55 & 81.70 & 71.25 & 68.40 & 64.60 & 63.65 \\
$0.075 \%$ Boric acid & 87.40 & 86.45 & 75.05 & 74.10 & 67.45 & 73.15 \\
$0.1 \%$ Boric acid & 94.05 & 91.20 & 78.85 & 76.00 & 71.89 & 72.80 \\
$0.2 \%$ Boric acid & 96.90 & 94.05 & 86.45 & 80.99 & 75.65 & 73.87 \\
New LSD 5\% & 8.12 & 8.34 & 8.86 & 9.10 & 8.63 & 8.44 \\
\hline
\end{tabular}


TABLE 7. Feasibility study for different treatments of calcium and boron onWashington navel orangeyield revenue.

\begin{tabular}{|c|c|c|c|c|c|c|c|c|c|c|c|c|c|c|c|c|}
\hline \multirow{2}{*}{ Treatments } & \multicolumn{3}{|c|}{ Yield /Feddan (Ton) } & \multicolumn{3}{|c|}{$\begin{array}{c}* \text { *Yield return/Feddan } \\
\text { (pound) }\end{array}$} & \multicolumn{3}{|c|}{$\begin{array}{l}\text { Treatment return/F } \\
\text { (pound) }\end{array}$} & \multirow{2}{*}{$\begin{array}{c}{ }^{*} \text { Treat. } \\
\text { Coast } \\
\text { (pound) }\end{array}$} & \multicolumn{3}{|c|}{$\begin{array}{l}\begin{array}{l}\text { Treatment profit } \\
\text { (pound) }\end{array} \\
\end{array}$} & \multirow[b]{2}{*}{2014} & \multirow[b]{2}{*}{2015} & \multirow[b]{2}{*}{ AVG. } \\
\hline & 2014 & 2015 & AVG. & 2014 & 2015 & AVG. & 2014 & 2015 & AVG. & & 2014 & 2015 & AVG. & & & \\
\hline Control & & 10.4 & & 13405 & 12885 & & 0 & 0 & 0 & 0 & 0 & 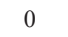 & 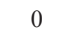 & 0 & 0 & 0 \\
\hline $0.5 \% \mathrm{CaCL}_{2}$ & 11. & 10.8 & 10 & 13753 & 13378 & 13566 & 348 & 494 & 421 & 39 & -42 & 104 & 31 & -0.3 & 0.8 & 0.2 \\
\hline $1.0 \% \mathrm{CaCL}_{2}$ & 11 & 11. & 11 & 1 & 5 & 12 & 983 & 1 & 1,007 & 570 & 412 & 461 & 43 & 20 & 33 & 3.1 \\
\hline $1.5 \% \mathrm{CaCL}_{2}$ & 12 & 11. & 1 & 15139 & 14514 & 14826 & 1,733 & 1,629 & 1,68 & 750 & 983 & 879 & 931 & 6.5 & 6.1 & 6.3 \\
\hline $2.0 \% \mathrm{CaCL} 2$ & 12.7 & 12. & 12.4 & 15753 & 15028 & 15391 & 2.348 & 2,144 & 2,246 & 930 & 1418 & 1214 & 1316 & 9.0 & 8.1 & 8.5 \\
\hline $0.05 \%$ Boric acid & 11.1 & 10.7 & 10.9 & 13722 & 13326 & 13524 & 317 & 442 & 379 & 237 & 80 & 205 & 142 & 0.6 & 1.5 & 1.1 \\
\hline $0.075 \%$ Boric acid & 11.8 & 11 & 11 & 14595 & 14476 & 14536 & 1,190 & 1,592 & 1,391 & 250.5 & 939 & 1341 & 1140 & 6.4 & 9.3 & 0 \\
\hline $0.1 \%$ Boric acid & 12.5 & 12.1 & 12.3 & 15491 & 15047 & 15269 & 2,085 & 2,162 & 2,124 & 264 & 1821 & 1898 & 1860 & 11.8 & 12.6 & 12.2 \\
\hline $0.2 \%$ Boric acid & 13.4 & 12.6 & 13.0 & 16624 & 15632 & 16128 & 3.219 & 2,748 & 2,983 & 318 & 2901 & 2430 & 2665 & 17.4 & 15.5 & 16.5 \\
\hline
\end{tabular}

*Washington navel orange/Ton: 1245 pounds

**Treatment Coast:included: material, spraying and labor coast where, Calcium Kg.:20 E. pounds Boron Kg.: 30 pounds

\section{Discussion}

The results obtained from the spray of $\mathrm{Ca}$ and B treatments showed the role of both calcium and boron on the vegetative growth parameters, fruit set $(\%)$, different stages of fruit drop (\%), yield and fruit quality of Washington navel orange trees. In this respect, in view of the preceding results it appears that foliarsprayswith boron have positive effects on the number of pollen tubes that successfully reached the ovule and on ovule viability significantly increased the number of flowers with double pistils Lovatt (1999). Moreover, boron stimulates ammonium assimilation in leaves and consequently increases protein concentration with greater boron dosages, supports assumption of a direct positive effect of boron on ammonium ion assimilation, alsoboron hada positive effect on the foliar activities of the enzymes involved in assimilating the $\mathrm{NH}_{4}^{+}$as glutamine synthetase, glutamate syntheses, glutamate dehydrogenase, and phosphoenolpyruvate carboxylase enzymes López-Lefebre et al. (2002). Boron could acts in the reaction medium by altering the conformation of the enzyme or by augmenting the affinity of some substrate or cofactor for the enzyme.

Still, Calcium is a divalent cation that is extremely important in maintaining the strength of stems and stalks of plants. This mineral also regulates the absorption of nutrients across plasma cell membranes. Calcium functions in plant cell elongation and division, structure and permeability of cell membranes, nitrogen metabolism, and carbohydrate translocation; thus it is a significant factor in inflorescence and flower formation and fruit quality (White, 2000).
In addition, it could be noted from previous data that boron applications had upmost calcium ones in most comparable parameters, which may be due to thatthe role of $\mathrm{B}$ maximized the $\mathrm{Ca}$ function by keepingit in a soluble form within the plant on a tissue basis rather than on a cellular basis (Wallace, 1961). Besides, it is thought to have a favorable influence on the absorption of cations particularly calcium, to have retarding influence on the absorption of anions and to have an essential part in carbohydrate and nitrogen metabolism (Batey, 1971).

Similar tendency was found with the application of B as borax or boric acid source (Kodua, 1980 on mandarin, Singh and Singh 1981 on mandarin, El-Hagab et al., 1983 on Navel orange and Balady mandarin trees, Ahmed et al., 1991 on Balady mandarin and Ahmed et al., 1996 on Balady mandarin). Also, Hegab et al., 2003 reported that spraying borax or boric acid on Washington navel orange trees at 0.025 to 0.2 caused a remarkable promotion in leaf area, length and diameter of shoot in the spring growth cycle and promoted the percentage of fruit setting. They found that using boric acid caused slight promotion on the growth. Also, Habasy et al. (2016) found that application for both $\mathrm{Ca}$ and $\mathrm{B}$ had an announced effect on growth, yield, percentages of $\mathrm{N}, \mathrm{P}$ and $\mathrm{K}$ in the leaves, leaf content of pigments and nutrients owing to spraying the trees with a mixture of chelated-Ca at 0.03 and chelated-B at $0.025 \%$ three times $\left(1^{\text {st }}\right.$ week of March, last week of April and $3^{\text {rd }}$ week of May).

These results are also partially agreed with the findings of El-Shobaky and Mohamed (2000)

Egypt. J. Hort. Vol. 44, No.1 (2017) 
and Aly et al. (2015) by foliar application with calcium. Deficiency of $\mathrm{Ca}$ and $\mathrm{B}$ had unfavorable effects on fruit quality (Nijjar, 1985). Also, Hegab et al. (2003), found that using boric acid caused slight promotion on fruit quality compared to borax.

Moreover, it has been reported that, growth, flowering, fruit setting, yield and fruit quality in citrus are positively affected by the application of B in the form of borax or boric acid Qin and Qin 1996 on orange; and Abd-El-Wahab, 1999 on Washington navel orange).

Generally, we may conclude that the figures attained from this study pointed out to that;spraying trees with Boric acid at $0.2 \%$ achieved the best results and the utmost profit followed by spraying calcium at $2 \%$. So,we may recommend applying both of treatments to gain more than either of their return; over and above get the advantages of boron affect on calcium mechanism in plant.

\section{References}

Annual Book of Agricultural Statistics, (2016) Cairo.

Abd El- Wahab, A.Y. (1999) Studies on the effect of foliar spraying with magnesium, boron and some vitamins on some vegetative and fruiting characters Washington navel oranges (Citrus sinensis Osb.), M.Sc. Thesis, Fac. Agric. Minia Univ.

Ahmed, F.F.,Darwish, O.H. and El-Sayed, M.A.(1991) Could alternate bearing of Balady mandarin trees (Citrus reticulate Blanco) be controlled by boron andmagnesium. Minia J. Agric. Res. Dev.,13, 3148.

Ahmed, F.F.,Ragab, M.A. and El-Dawwey, G.M.(1996) Response of Balady mandarin trees grown on new reclaimed sandy soil to spraying boron. Fourth Arabic Conf. for Hort. Crops, El-Minia, Egypt Part 11, Pomology, pp. 1009-1018.

Aly, M.A.,Harhash, M.M., Rehab M.A. and El-Kelawy, H.R. (2015) Effect of foliarapplication with calcium, potassium and zinc treatments on yield and fruitquality of Washington navel orange trees. Middle East Journal of Agriculture Research, 4, 564-568.

A. O. A. C. (1965) Official methods of analysis pp 490-510.Association of official analytical chemist$s$ washington, D. C.
Batey, T. (1971) Manganese and boron deficiency. Trace elements in soils and crops. Technical Bulletin, 21. Her Majesty's Stationary Office, London, pp: $137-148$.

Chapman, H.D. (1960) Leaf and soil analysis in citrus orchard.University of California, Division of Agricultural Science, Berkeley, Manual 25.

Chapman, H.D. and Pratt, P.E. (1978) Method of analysis of soil, plants and waters. Division of Agricultural Science, University of California, Berkeley.

Chiu, T.F. and Chang, S.S. (1985) Diagnosis and correction of boron deficiency in a citrus orchard of Taiwan. Tech. Bull. Food and Fertilizer Tech. Bull. Food and Fertilizer Tech. Center No. 91, pp. 1-11.

Dela-Fuente, R.K., Tang, P.M. and Guzman,C.C., (1986). Pant growth substances, 1985: Plantenvironment interactions. Wilkinsin, R.E. (Ed.). Proceedings of the $12^{\text {th }}$ International Conference on Plant Growth Substances, August 26-31, 1985, Madison Avenue, New York, USA.

El-Hagab, M.H., Higazi, A.M., El-Naggar, S.Z., Ahmed, S.A. and Hassan, A.M. (1983) Effect of soil and foliar fertilization on growth of Navel orange and Balady mandarin trees. Minufiya J. Agric. Res.,(7), 261-279.

El-Shobaky, M.A. and Mohamed, M.R.( 2000) Effect of calcium and potassium foliar application on leavesnutrients content, quality and storage life of citrus (Washington Navel Orange) under drip irrigation in clay soil. J. Agric. Sci. Mansoura Univ., 25 (12), 8027-8037.

Evenhunis, B. and DeWaard, P.W. (1980) Principles and practices in plant analysis.F.A.O. Soils Bull.,38(1), 152-163.

Faust, M. (1975) The role of calcium in the respiratory Mechanism and senescence of apples. Res. Scientific 238, 87-92 (Hort. Abs., 46: 2911).

Habasy,R.E.Y.,Helal,M.E.; Abd El-Rahman, A.M. and Ahmed, F.F. (2016) Effect of calcium and boron sources and methods of application on growth, yield and fruit quality of Washington navel orange trees. J. Agric. Sci.Ain Shams Univ., 24 (1), 185193.

Hegab, M.Y., Shaarawy, A.M.A. and Taaya, I. A.H. (2003) Effect of different sources and concentrating, yield and fruit quality of Washington navel orange trees. Minia J. Agric. Res. Develop., 23 (1), 83-96. 
Jackson, M.I. (1967) "Soil Chemical Analysis", Perentice Hall of India Private Limit. New Delhi.

Kodua, M.A. (1980) Effect of boron and manganese on mandarin yield and quality. Referativnyl Zhurnal, 11, 540-546

López-Lefebre, L. R., Ruiz, J.M., Rivero, R.M., García, P.C., Sánchez, E. and Romero, L. (2002) Supplemental boron stimulates ammonium assimilation in leaves of tobacco plants (Nicotiana tabacum L.). Plant Growth Regulation., 36, 231-236.

Lovatt, C.J. (1999) Timing citrus and avocado foliar nutrient applications to increase fruit set and size. Hort. Techno., 9, 607-612.

Nijjar, G.S. (1985) Nutrition of fruit trees. Kalyani Publisher, New Delhi-India, pp. 206- 234.

Poovaiah, B.W. and Leopold, A.C. (1973) Role of calcium in prolonging storage life of fruits and vegetables, food Technology, 5, 267-270.
Qin, X. and Qin, X.N. (1996) Foliar spray of B, Zn and $\mathrm{Mg}$ and their effect on fruit production and quality of Jincheng orange (Citrus sinensis) J. of Southwest Agric. Univ.,18, 40-45.

Singh, R. and Singh, R. (1981)Effect of nutrient sprays on granulation and fruit quality of Dancy Tangerine mandarin. Hort. Abst., 51, 73-86.

Snedecor, G.W. and Cochran,W.G. (1980) "Statistical Methods", Iowa State Univ. Press, Iowa. U.S.A.

Tariq, M. and Mott, C.J.B. (2007) Effect of Boron on the Behavior of Nutrients in Soil-Plant Systems-a Review. Asian Journal of Plant Science, 6, 195 202.

Wallace, T., (1961) Essential Points in the Nutrition of Plants: The Diagnosis of Mineral Deficiencies in Plants by Visual Symptoms, $3^{\text {rd }}$ ed., Her Majesty's Stationary Office, London, pp. 5-17.

White, P.J. (2000) Calcium channels in higher plants. Biochem. Biophys. Acta, 1465, 171-189.

\section{تأثير المعاملات المختلفة للكالسيوم والبورون على الإنتاجية وصفات الجودة والقدرة التخزينية لثمار البرتقال أبو سرة لأبرة \\ علي رزق فرحات هيكل ، مجدى عبد الفتاح ابراهيم و رضا عبدالله عبد العزيز معهد بحوث البساتين ـ مركز البحوث الزراعية ـ القاهرة ــ مصر.}

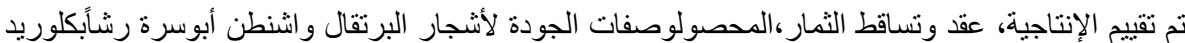

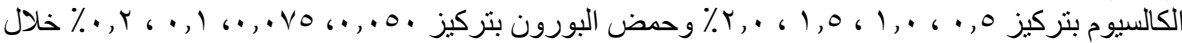

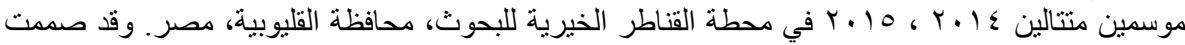

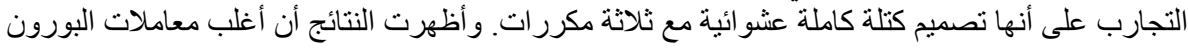

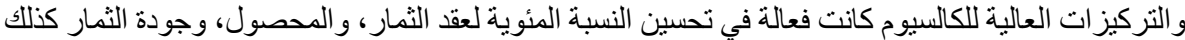

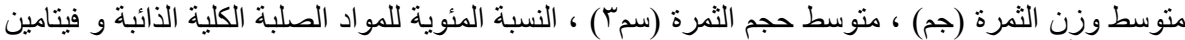

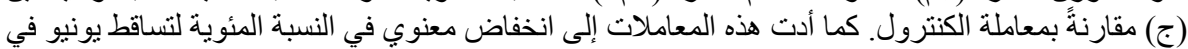

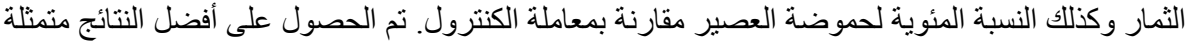

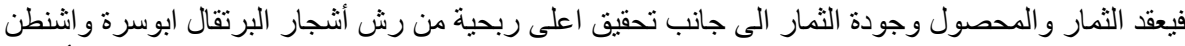

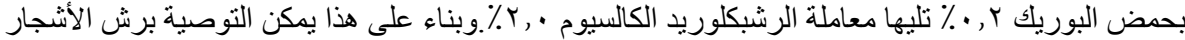
بكلا المعاملتان لتحقيق أعلى انتاجية و اكبر معدل من الربحية. 